\title{
User Central Content Design in the Age of Interactive Television*
}

\author{
Birgül Taşdelen (Asst. Prof. Dr.) \\ Gümüşhane University Faculty of Communication \\ birgultasdelen@gmail.com \\ ORCID: 0000-0003-0281-3892 \\ Mehmet Kesim (Prof. Dr.) \\ Anadolu University Open Education Faculty \\ mkesim@anadolu.edu.tr \\ ORCID: 0000-0002-8153-5159
}

Date Received: 28.08.2019

Date Accepted: 26.12.2019

Date Published: 24.01.2020

DOI: http://10.17680/erciyesiletisim.612545

\section{Abstract}

The purpose of this study is to develop an interactive prototype for interactive television content design. The development process of the prototype for interactive television broadcasting consists of two stages. At the first phase of the process, eight experts' opinions were asked who accepted to take part in the study and are experienced in interactive TV and content from Netherlands, the USA, Australia, Singapore and Turkey. Therefore, this study is structured as a qualitative case study. According to the data obtained from the research, it was concluded that the design principles for interactive television broadcasting and the interactive applications for these principles carried out with 4 themes. These themes; creating interactive content appropriate to the visual language and aesthetics of television, second screen application in interactive television broadcasting, supporting control elements in line with the individual differences of the participants and providing online applications. In the second process step, in accordance with the data gathered from these interviews were applied to an interactive football program design. As a result, the content design created for each program offers the user a different level of interactive environment. Whether the program is appropriate to the visual language and aesthetics of television affects the user's behavior, the quality and naturalness of the interaction presented. The higher the number of online parameters changed in interactive football design, the higher the level of user participation in the football program. The level of interactivity in the football program is related to the interaction of the participants by making meaning through the personal symbols transmitted and the involvement of the participant in the content at the point of reciprocity, responsiveness and responsiveness.

Keywords: Interactive, Interactive Tv, Qualitative Research, Interactive Football Design.

\footnotetext{
* This study is supported by Anadolu University Scientific Research Commission (Project no: 1402 E 028) and a part of PhD dissertation written by Birgül Taşdelen in 2015.
} 


\title{
Etkileşimli Televizyon Yayıncılığında İçerik Geliştirme*
}

\author{
Birgül Taşdelen (Dr. Öğr. Üyesi) \\ Gümüşhane Üniversitesi İletişim Fakültesi \\ birgultasdelen@gmail.com \\ ORCID: 0000-0003-0281-3892
}

Mehmet Kesim (Prof. Dr.)

Anadolu Üniversitesi Açıköğretim Fakültesi

mkesim@anadolu.edu.tr

ORCID: 0000-0002-8153-5159

\author{
Başvuru Tarihi: 28.08.2019 \\ Yayına Kabul Tarihi: 26.12.2019 \\ Yayınlanma Tarihi: 24.01.2020 \\ DOI: http://10.17680/erciyesiletisim.612545
}

\section{Öz}

$\mathrm{Bu}$ makale, etkileşimli televizyon içeriklerinin tasarımına yönelik interaktif bir prototipin geliştirilmesini amaçlamaktadır. Etkileşimli Televizyon Yayıncılığına ilişkin prototipin geliştirilmesi süreci iki aşamadan oluşmaktadır. Sürecin ilk aşamașnda Hollanda, ABD, Avustralya, Singapur ve Türkiye'den çalışmaya katılmayı kabul eden etkileşimli televizyon ve etkileşimli içerik konusunda deneyimli sekiz uzmanın görüşleri alınmıştır. $\mathrm{Bu}$ nedenle araştırma, nitel bir durum çalışması şeklinde desenlenmiştir. Elde edilen veriler doğrultusunda, etkileşimli televizyon uygulamalarının dört ana tema ile gerçekleștirileceği sonucuna ulaşılmıştır. Bu temalar; televizyonun görsel diline ve estetiğine uygun etkileşimli içerik oluşturma, etkileşimli televizyon yayıncılığında ikinci ekran uygulaması, katılımcıların bireysel farklılıklarına uygun olarak destek kontrol unsurların yer alması ve çevrimiçi uygulamalara yer vermedir. Sürecin ikinci aşamasında ise, bireysel görüşmelerden elde edilen veriler doğrultusunda etkileşimli bir futbol programının tasarımı gerçekleştirilmiştir. Sonuç olarak her bir program için oluşturulan içerik tasarımı, kullanıcıya etkileşimli çevrenin farklı düzeyini sunmaktadır. Pogramın televizyonun görsel diline ve estetiğine uygun olup olmama durumu, kullanıcının davranışını, sunulan etkileşimin niteliğini ve doğallığını etkilemektedir. Etkileşimli futbol tasarımında değiştirilen çevrimiçi parametrelerin sayısı ne kadar çok olursa, kullanıcının futbol programına katılım düzeyinin kalitesi de o kadar artmaktadır. Futbol programında etkileşimlilik seviyesi, etkileșim içerisinde bulunan katılımcıların iletilen kişisel semboller üzerinden anlam oluşturmasıyla ve içeriklerde karşılıklılık, yanıt verme ve yanıt verme hızı noktasında katılımcının sürece dahil olmasıyla ilgilidir.

Anahtar Kelimeler: Etkileşim, Etkileşimli Televizyon, Nitel Araştırma, Etkileşimli Futbol Tasarımı.

\footnotetext{
* Bu çalışma, Anadolu Üniversitesi Sosyal Bilimler Enstitüsü'ne 2015 yılında sunulan ve Anadolu Üniversitesi Bilimsel Araştırmalar Komisyonunca destelenmiş (Proje no: 1402 E 028) "Etkileşimli Televizyon Yayıncılığında İçerik Geliştirme” başlıklı doktora tez özetidir.
} 


\section{Introduction}

The addition of interaction in television is generally accepted that the concepts of viewers and consumers are also under the influence of this transformation. With the phenomenon of interactivity, the listener, reader, and viewer; which normally implies a passive stance in traditional mediums, are transformed into a post audience, seamlessly integrated in social networks, content databases, and interactive applications, assuming an active role in the medium (Faber, 2011, s. 34; Rafaeli, 1988, s. 121), thereby bringing forth the interactive nature of communication. This, in turn, helps us understand the reactions to the communications process of individuals participating in interactive mediums.

Content is an important element for interactive TV to truly become an alternative to other broadcast methods. Therefore, it is believed that the greatest leverage of a successful interactive service lies in content creation, as infrastructure and attractive user interfaces are considered insufficient (Pagani, 2000). This situation suggests that an interactive television structure in which content creators are truly active will emerge. It is believed that the most commendable aspect of new media is the content in which technology combines history and innovation (Kim, 2009, s. 543-544). Therefore it is important that content development for interactive television broadcasting, or in other words providing users with content they would desire, and the benefits of content to the system, is studied.

Other than publications regarding consumer expectations, business models, and service regulations, academic studies on interactive television are quite few (Bouwman, Zhengjia, Duin and Limonard, 2008, s. 23). Diverging from research that studies the technical and economic aspects of interactive television, research on the information provided by experts in content development would enrich the field. Thus, the main purpose of this study is to design and apply an interactive system for the content of interactive television.

\section{Interaction as Definition}

In order to better understand the characteristics of the concept of interaction, which has an important place in terms of communication sciences, it will be appropriate to first define it. According to Quiring $(2009$, s. 899), with the great tendency towards interactive technologies in the late twentieth century, the term interactivity is defined with the concepts of interactive and interaction that are close to it and there is an ambiguity in the academic language related to these terms. For this reason, it is necessary to define the interaction, interactive and interactiveness terms for a better understanding according to Yüzer (2013, s. 57). The term "interaction" is movement, and effect. In this context, there appear the presence of tools, actions or participants in communication, such as websites converged into multimedia aspects, computer softwares, online services and educational environments in which students engage in dialogue with the instructor in the emergence of the interaction. The term "interactive" refers to the mutual relationship between two or more persons or object-tools that are engaged (OxfordDictionary, 2013). The term is used to describe the interactive processes taking place between person-person, person-tool or tool-tool. The same term also imposes a special meaning in computer environments. According to this specific meaning, the term refers to the flow of communication between user inputs, interactive interfaces and user (OxfordDictionary, 2013). In terms of this definition, it is possible to look at the term interactive as a term that qualifies technologybased systems that can respond to the input of the participants in the communication process. For example, the interactive word from interactive television perspective refers to the medium/tool that technically meets user requests. 
Interactivity is defined in the simplest was as the interaction of two or more participants by the simultaneous interaction of the communication medium and the message (Liu and Shrum, 2002, s. 54). According to Richards (2006, s. 532), it may be an effective way for interactive communication studies to formulate interactivity as a feature of both the means of communication and the production and sharing of a series of interconnected information. Thus, the term may suggest a medium, a dialogue, or an activity, as well as suggesting an interactive environment that can respond to messages from the user (Bietz, 2008; Andrejevic, 2009, s. 36). However, in most studies about interaction, it is seen that they focus only on one of these two meanings.

\section{Interactive Television as a Concept}

If we were to separate the developments that have taken place since the inception of television into eras, the first era would begin in 1931 with the emergence of the functional black-and-white television, the second era would be the prevalence of color broadcasting in the 1960's (Abramson, 2003, s. x), and the final era would be the transfer to interactive television in the second half of the $20^{\text {th }}$ century with the combination of telecommunication, digital television broadcasting, and the internet (Tsekleves, Cosmas, Aggoun and Loo, 2009, s. 2).

Kim and Sawhney (2002, s. 222) state that with the proliferation of interactive media, television broadcasting gained a new front; in fact it is considered a deeper change than the single important development in the 60 year history of television, namely the transfer to color television. Due to these aspects, the passive experience of television viewing is, if requested, transformed into an interactive, participative communication experience (Athanasiadis and Mitropoulos, 2010, s. 1454). In this regard, interactive television may be defined as follows: a television that enables two-way communication while entailing various communication stages through applications run on a telephone, internet line, or set-top box. In addition to the television, more devices and technologies such as telephone lines, internet connections, and set top boxes are considered a part of interactive television.

\section{Content in Interactive Television Broadcasting}

In traditional broadcasting, the content flow is sent to a large number of recipients at different locations, simultaneously and linearly. In interactive television broadcasting, by breaking the bureaucratic control on the content, the receiver can send and receive a message to any point with a network connection. This enables messages to be personalized, enabling them to be accessed anywhere and anytime (Lotz, 2014, s. 32). Chen (2007, s. 95) relies on the influence of new media on the lives of individuals, limiting the sovereignty of the sender, the elimination of homogenized masses, the new movement of people using innovations, and the emergence of new cultural forms due to this mobility. The interactive media offers a platform where the user can perform various purposes such as content transportation, chat among users, information sharing and online shopping (Rogers, Sharp and Preece, 2011, s. 175). Thus, the interactive media separates the traditional media from the broadcast line and increases the user's dependence on the content distribution by interactive means.

Content produced for interactive television broadcasting allows viewers to directly interact with the television program. Rather than how the interaction process is covered, designers must focus on the script, shooting, editing, and every aspect based on the desired level of interactivity towards satisfying user perceptions and needs regarding 
producing content for an interactive television program. Throughout the 1990's, studies on interactive television focused on actually providing digital television and increasing the efficiency of digital television broadcasting, while current research focuses on efforts to increase personalization, interactive narratives, and providing interactive television experiences through media technologies. The television industry is moving from a model in which the broadcaster pushes content to the client, towards a model in which the consumers pull the desired content to themselves.

According to Cesar and Chorianopoulos (2008, s. 283), studies throughout the 1990s focused on interactive television research, digital television broadcasting and video compression techniques, and increasing digital television broadcasting, whereas the main problem of the twenty-first century studies is to provide interactive television experiences through individualizing efforts, interactive narratives and media technologies. According to Ha and James (1998, s. 459), technology is evolving from a mass production and mass consumption area to a feast where diversity is endless. The traditional view on content flow is summarized by Cesar and Chorianopoulos (2008, s. 291) in Figure 1.

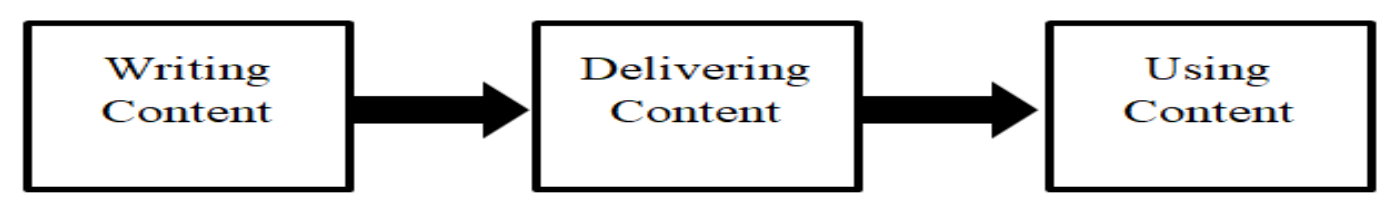

Figure 1: A Simplified View of Hierarchical Content Stream Source: Cesar and Chorianopoulos, 2008, s. 291.

Television content is traditionally made in studio environments that use digital tools. The produced information stream is structured from the ground to the ground or from the center to the periphery without feedback. According to Akca $(2008$, s. 50), the aim of traditional television is to reach the audience. Therefore, programs are addressed to the majority. Video surveillance and video sharing over the Internet has been the most important event in the worldwide internet network. The flow of multimedia content began with the ability to record the media. Common features of next-generation web video sites with interactive content such as YouTube, Yahoo, MySpace, Flickr provide easy-to-use interfaces for video surveillance, scoring and video sharing (Cesar and Chorianopoulos, 2008, s. 290).

Developed for personal computer use, this new generation of video sites has started the tradition of sharing user-generated content in visual media. The Internet has given people the opportunity to watch the content they want at any time, and this same desire was born for television. The television industry now shifts the content from the model that the publisher pushes to the customer, to the model that the consumer wants. In the interactive television architecture, the audio/video content is stored on the storage medium by the service provider before it is processed. In the interactive television architecture, the audio/video content is stored on the storage medium by the service provider before it is processed. The content is then coded according to the design elements of the communication means and the interface functions for the user interaction. These codes are written in accordance with the structural characteristics of each medium. Finally, the processed content is sent to the "end user's" device compressed for consumption (Ersavaş, 2008, s. 139-141). In Table 3, Cesar and Chorianopolous compare the content flow presented by traditional broadcasting and the flow of content presented by interactive applications. 
Table 1: Comparison of the Traditional Perspective and New Emerging Paradigm in Content Flow

\begin{tabular}{|c|c|c|c|}
\hline Topic & Sub Topic & Traditional Paradigm & $\begin{array}{l}\text { New Developing } \\
\text { Paradigm }\end{array}$ \\
\hline \multirow{3}{*}{ Editing Content } & Data overlay & $\begin{array}{l}\text { Professional production } \\
\text { Professional metadata }\end{array}$ & $\begin{array}{c}\text { User generation } \\
\text { User tags (classification) }\end{array}$ \\
\hline & Software & Patented systems & $\begin{array}{l}\text { Web-based systems } \\
\text { IPTV solutions }\end{array}$ \\
\hline & Mash-ups & Studio increases & User increases \\
\hline \multirow[t]{2}{*}{ Sharing Content } & Topology & $\begin{array}{l}\text { Terrestrial, wired and satellite } \\
\text { / Fixed user connections } \\
\text { / Publisher or user- } \\
\text { distributor architecture }\end{array}$ & $\begin{array}{l}\text { Mobile distribution of content } \\
\text { Content broadcast by user } \\
\text { / P2P technologies }\end{array}$ \\
\hline & $\begin{array}{c}\text { Content rights } \\
\text { management }\end{array}$ & Closed system & Content sharing between users \\
\hline \multirow[b]{2}{*}{$\begin{array}{l}\text { Monitoring } \\
\text { Content }\end{array}$} & Content selection & Suggestion systems & Content-based research \\
\hline & Content navigation & $\begin{array}{c}\text { Functionality like Electronic } \\
\text { Program Guide } \\
\text { Video Cassette Recorder- } \\
\text { like functionality }\end{array}$ & $\begin{array}{l}\text { Group-based research } \\
\text { Semantic navigation of content }\end{array}$ \\
\hline
\end{tabular}

Table 1 shows that the traditional paradigm in the form of "write, distribution, and watch", which is relevant to the content in the traditional publishing, has been replaced by three main components: "edit, share and supervise". According to Cesar and Chorianopoulos (2008, s. 284-285), the viewer is considered to be an active node in the content creation chain, since personalization comes to the fore. The interactive television viewer has the expectation of generating content over their consumption through easy-to-use applications. Content sharing, which corresponds to content distribution activities in traditional television broadcasting, is a communication process through which interactive services such as P2P (pear-to-pear) interact with a friend about the program they are watching, with simultaneous (while watching) or asynchronous (after watching) sharing of files such as movies, music, photos. Finally, content control is related to "what the user will watch" by choosing the process and "how and where" she/he will follow through the consumption of the process. For example, with the Catch-Up TV service, the user can watch the program he / she misses in the broadcast stream at any time. According to Baștan (2009, s. 207), designers create interfaces for a higher interactivity, based on the user's ability to take advantage of arbitrary selection possibilities and to find his own way in almost unlimited choices. Differences between traditional media and useroriented media about content production, distribution and interaction opportunities are summarized in Figure 2. 
Traditional Media

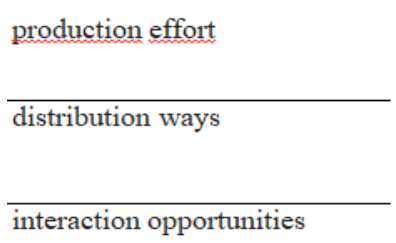

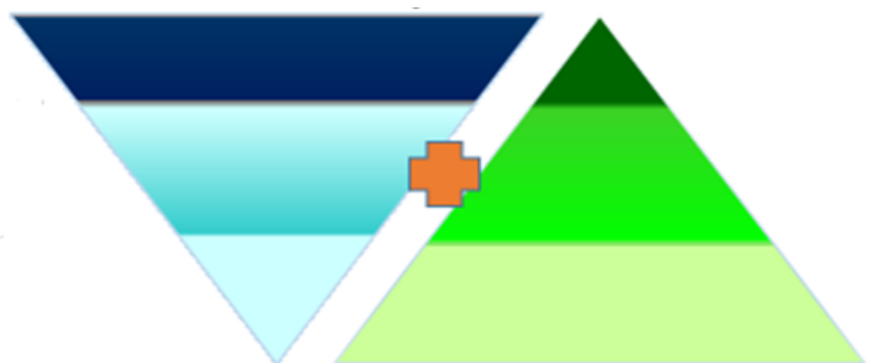

User-Oriented Media

Figure 2: Comparison of Traditional Media and User-Oriented Media Source: Guimarães, 2009.

\section{Purpose of the Research}

One of the most important tools for interactive TV to be an alternative to other broadcasting methods is content. For this reason, it is thought that it is not enough to establish an infrastructure and provide attractive interfaces to the audience for a successful interactive service and to produce content is the biggest trump in success (Bayrak, 2008, s. 175). This shows that there will be a structure in which interactive content producers may be effective. According to Ünaldı (2010), television companies that have distribution channels will be able to search for content because they cannot be effective by using existing distribution structures, so content producers will gain significance. According to Kim (2009, s. 543-544), commercial, engineering and legal features are the leading factors in new media studies; however, these features are not an important problem for new media studies. The most important problem of the new media is the content that combines the historical and innovation part of the technology. Therefore, this study will help to understand the relationships between the new orientations created by the interaction in communication environments since the beginning of the internet age, to reveal the problems, to explain the cause and effect relations and to design and develop the contents in accordance with the requirements of the era, audience needs. The main purpose of this research is; to design and implement an ideal system for the design of interactive television content in accordance with expert opinions. In the context of the literature review, the research aims to answer the following from semi-structured in-depth interviews:

What are the possibilities of interactive television broadcasting?

What is the role of interactive television in providing a sense of coexistence?

What is the relationship between the creation of interactive content and the current structure of television?

What is the effect of individual differences (age and educational level) on the interactive content structure?

What is the effect of elements added to the interactive environment (animation, text, sound) on the user's viewing process?

What content editing opportunities should the user have to ensure the success and sustainability of the program? 


\section{Method}

Unlike the studies that generally deal with the technical and economic dimensions of interactive television, examining the information to be provided by experts in content determination will enrich the studies in this field. Since it was aimed to develop a system for the design of interactive television contents, the study was designed as a qualitative case study. Case study, which is one of the qualitative research types, is related to a comprehensive examination of the data obtained through participatory observation, indepth interviews and document collection on one or more events (Glesne, 2013, s. 30). Participants in this study were selected through purposeful sampling. In purposeful sampling, the researcher chooses the sample among the people who can give the most appropriate answer for their purposes. For this reason, purposeful sampling leads to the selection of situations that have rich information in terms of reaching enlightening information and providing an in-depth understanding of the subject (Patton, 2002, s. 45-46).

In the process of identifying the participants of this research, the resume information of the experts who have accumulated knowledge about interactive television and content software and contributed to the field through their studies were examined in October 2013 and a total of 100 experts from Turkey and abroad were sent a call for participation via e-mail. After waiting for a sufficient period of time, experts were asked whether they would like to participate in the research by e-mail to remind them. 2 participants from Turkey, 2 from the Netherlands, one from the United States, one from Australia and one from Singapore, totally 8, have responded positively to the call for expert participation. This research was stated that an individual interview was planned to take about 45-50 minutes. The researcher then sent an Interviewee Information Form in two copies to each participant, explaining the purpose of the research, the rights of the participants and that their identity documents would be kept confidential. Since the research focuses on the design of content production for interactive television broadcasting, attention has been paid to the selection of experts from the background of interactive television and content software. Therefore, the participants of the research consist of faculty members and media professionals who have at least five years of experience contributing to the literature through their national and international studies and / or actively involved in the content design process. Semi-structured interviews (DiCicco and Crabtree, 2006, s. $315)$, which is one of the techniques commonly used in many studies, consists of openended questions (Flick, 2014, s. 197). The aim of open-ended questions is to capture the participants' ideas in their natural situations without affecting the participants with original predetermined options (Patton, 2002, 21). One of the strengths of the research is the validity and reliability of the research, such as the creation of the field literature, the development of data collection tools used in the data collection process and the analysis of data, all within the framework of the control of two experts who are qualified in qualitative research methods. In this study, 25 semi-structured interview questions which were formed from the theoretical framework of the research were used. The researcher conducted individual interview questions consisting of open-ended questions and two pilot interviews with two different faculty members. In each pilot interview, an expert participated in the qualitative research methods with the researcher and observed the interview process and guided the researcher after the interview. After the completion of the individual interviews, the researcher created a separate folder on the computer for each participant interviewed face-to-face and via email. The researcher converted the voice recordings recorded during the face-to-face interview process into a word 
document and uploaded all the individual interviews to the previously created folders on the computer together with the data obtained via email and obtained as text. After this stage, the researcher read the transcripts he/she uploaded to the computer repeatedly and the answer related to each question was found from the whole transcript and realized by piling under the related question. In this way, the data is named to create meaningful sections within itself, in other words it is coded.

The purpose of this study is to develop a system with expert's opinions. In order to determine the views of experts is used content analysis method. In this study views of experts were analyzed via Nvivo 10. As the goal of the study is to develop a system for designing interactive television content, the study is conducted as a case study. In qualitative research it is also intended to in-depth understanding events or the relationship of the state instead of making guesses about the future (Patton, 2002, s. 14). The participants of the study are academics and media professionals with at least five years of experience in the field, whom have an active role in the process of content design or whom have contributed to the literature in the field with national and international studies. The data gathered through individual interviews with 8 experts selected through purposive sampling was coded using the Nvivo10 software. While analyzing the individual interviews, in accordance with the structure of the aforementioned software, various themes were determined and coding was conducted in accordance with these themes. Each individual code was coded with at least one theme. Based on the codes and themes obtained through the data analysis conducted within the study, an interactive football design was undertaken. The themes comprised in the study are; text should be larger than 22 point, effects should not last longer than 0.5 seconds, animations should not hinder or obstruct the video, color harmony, data connections between sources over the internet should be established, ensuring the viewer is more active, including the participating viewer in organizing content, providing the user the opportunity for interaction, contribution to content continuity, preferring easy interfaces, determining the target audience, information access and sharing information with other users, realization of a personal viewing experience, simultaneous presentation of video and information.

\section{Findings}

In light of the findings obtained through the data analysis conducted in the study, a four dimensional model in which all the dimensions interact with each other is established and portrayed in Figure 1. General codes and themes were established from the different and detailed data sets during the analysis of the qualitative data in the study (see Figure 1). 


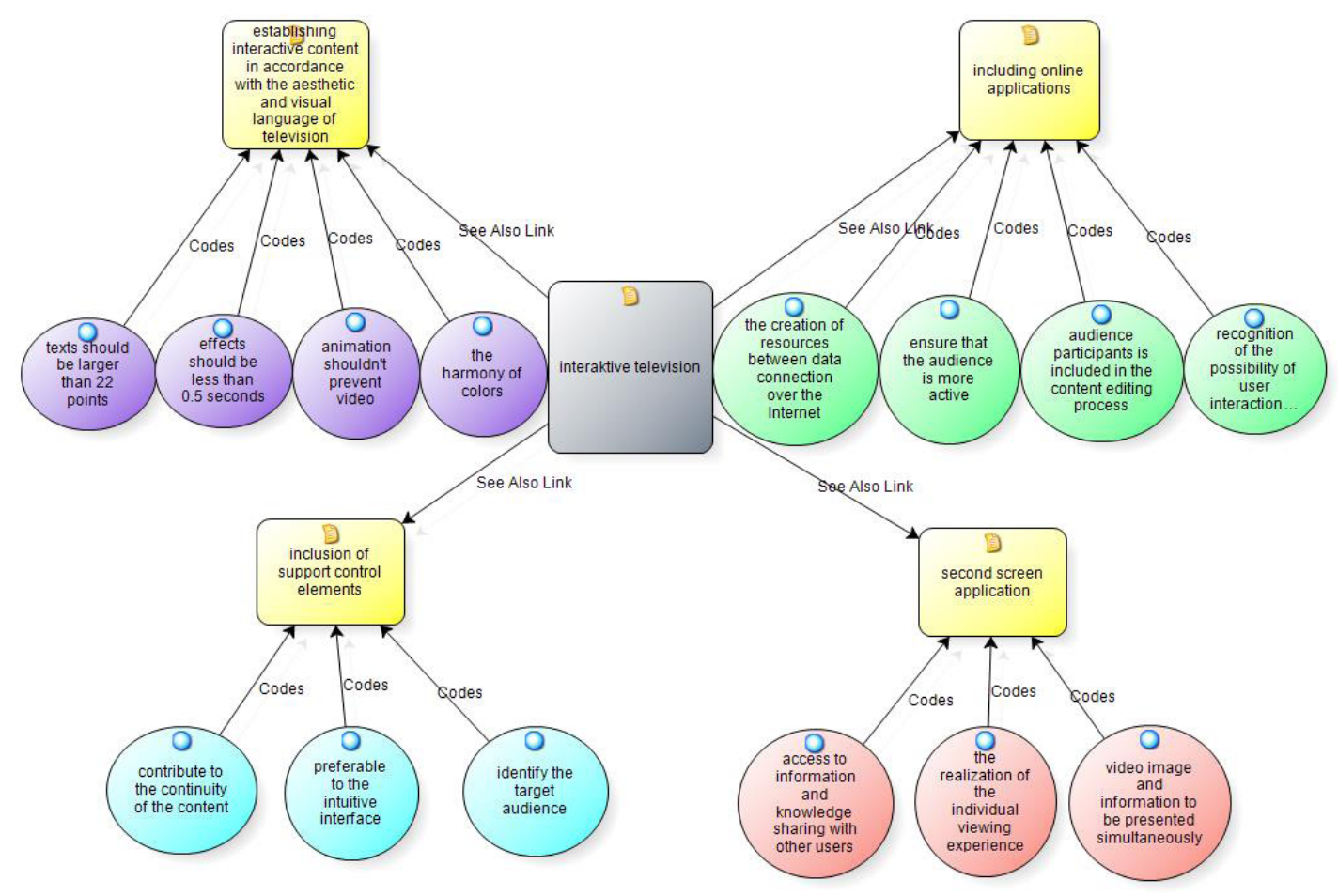

Figure 1: General Codes and Themes in the Qualitative Research.

As a result of content analysis revealed teams and subteams provided in the Figure. The four dimensions of the model are as follows:

1. Establishing interactive content appropriate for the visual language and aesthetic of television, (create interactive content suitable for the visual language and aesthetic of television)

2. Second screen application in interactive television broadcasting,

3. Presence of support control elements appropriate for the individual differences among participants

4. Presence of online applications. (give place to online application)

based on the codes and themes obtained through the data analysis conducted within the study, an interactive football design was undertaken.

\section{Establishing interactive content in accordance with the aesthetic and visual language of television:}

Within the study, regarding establishing interactive content without disrupting the structural qualities of television, experts stated that in addition to ensuring visual integrity in interactive program design, design elements that may distract users must also be avoided to maintain cognitive integrity. Direct quotes from experts given below;

Too much detail can reduce the attractiveness of the program. The point to be noted here, forming a part of the composition of each function in the image. Therefore the composition formed with elements such as color, light, line, perspective, composition, balance by the director should be strengthened with the help of camera movement, lenses, animation visual and audio effects. (Wesley) 
...The objects to be placed on the frame must be placed in accordance with the television picture format. I think two-thirds of a part of the frame ground is an appropriate space for visual composition. (Anthony)

Even if the lowest levels of television watching, on the screen to open additional menus or interface functions can irritate the audience. Interface functions can be configured so that it can be activated by viewers during the broadcast. In addition, the page will be opened in the screen size should not affect the television viewing behavior. (Deniz)

Therefore, it is important that during the design of interactive television content, care must be taken regarding situations that may confuse viewers and distract the television viewing process such as not including contextual information, establishing content that requires further manipulation, and web content that is not designed in accordance with the program. Based on the data gathered from experts, the following are required for intelligible and consistent content design for designing an uncomplicated screen:

- Animations used in interaction on the screen should not hinder or obstruct the video,

- Due to the structure of the television screen, textual information should be included on screen in small sections, larger than 22 points, with sufficient line spacing,

- Avoiding using contrasting colors on the screen that may influence the viewers' attention, utilizing colors harmoniously, being aware of the physiological and psychological effects that colors on the screen induce,

- Using audio stimuli outside of viewing and keeping effects shorter than 0.5 seconds.

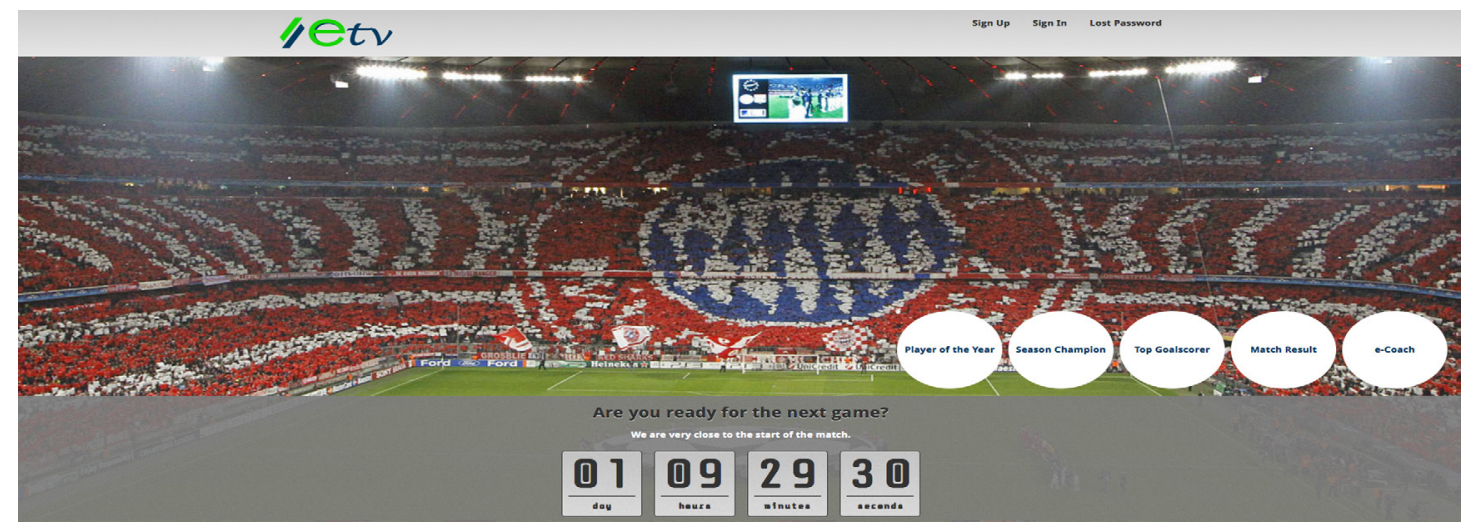

Figure 2: Different Elements in Interactive Football Design.

In the interactive football match established in accordance with the first stage of the model, establishing interactive content in accordance with the visual language and aesthetic of television, a straight-lettered font was selected to ensure users could easily follow and understand the consistent screen order. Graphics utilized for interaction are placed translucently in the bottom corner of the screen so as not to interfere with the video. In addition, care was taken to ensure that the effects do not last more than 0.5 seconds.

\section{Including online applications}

Experts indicated regarding including online applications in interactive television broadcasting design that it is an important aspect of the design process of user centered content creation and that when designing this aspect, applications that will promote the viewer to be more active, and assist to provide more information regarding the content. 


\section{Direct quotes from experts given below;}

With interctive television banking, shopping,pay TV, pay per wiev, games, nonlinear content flow are possible, VOD and NVOD applications can be presented to the audience.(Junhui)

Another expret, Bram, says; the viewer is included in the content organization process through online applications. Through opportunities such as portraying match scores to the viewer, choosing between different camera angles, and participating in competition programs as a competitor, the participant will add their own appreciation to the content and continue with their own manner of viewing.

In the interactive football application designed in accordance with the quotes, through the ability to choose different video and audio channels the user may watch the match in their own way, closing the commentator audio and watching the match with only the sounds of the sports fans if they wish. Additionally, they may follow their favorite player through different camera angles or cheer for their team in the chat room, goad their rival fans, join the forums to comment on events that take place in the match (goals, fouls, referee calls etc.), gather information on the players, use the "who should analyze the game" application to request that the sports expert of their choosing analyzes the match after it has concluded, and use the "Footballer of the Year" application to vote with viewers to determine the footballer of the year (see Figure 3).
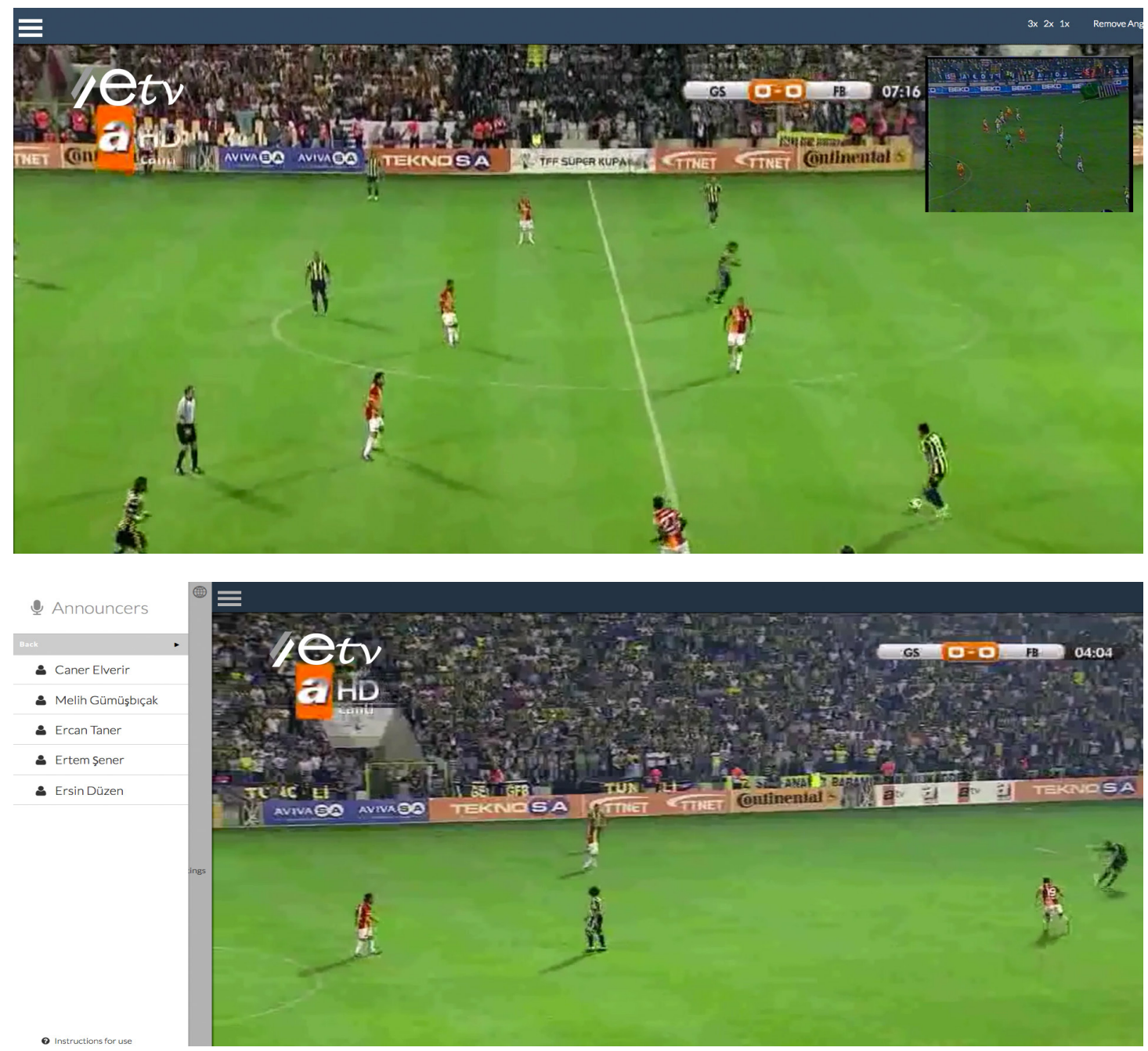


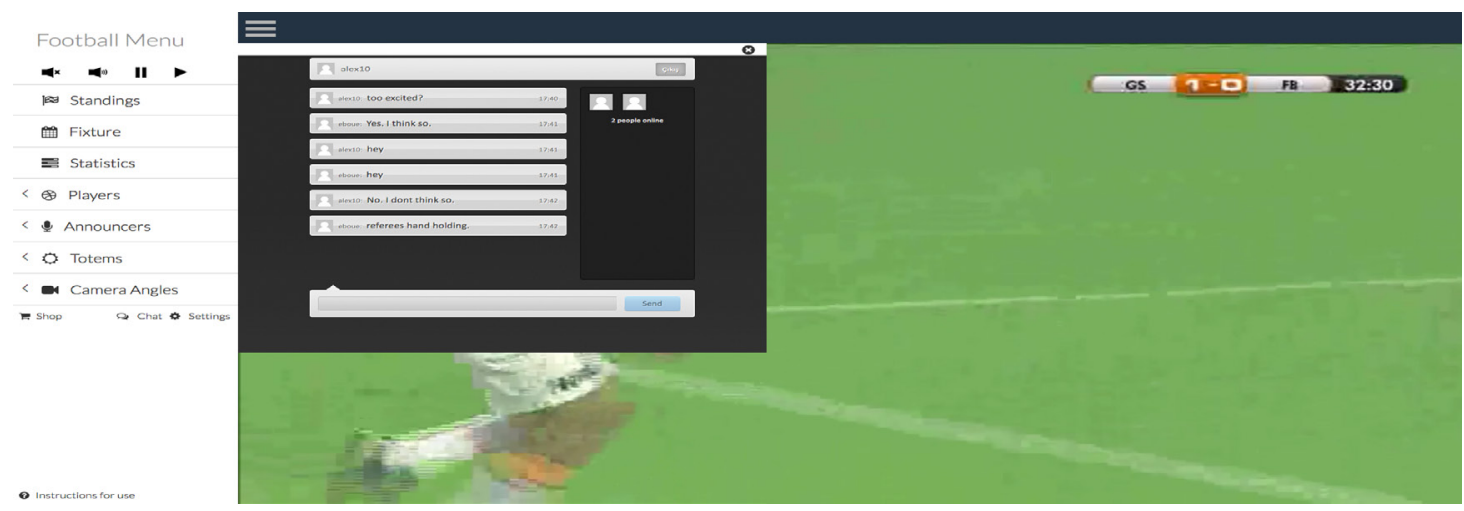

Figure 3: Examples of User Centered Online Applications.

Additionally, various interactive totem applications were designed for users. One such application is the screen blackout application (see Figure 4). The screen blackout application allows the user to black out the screen during a goal rather than close their eyes. Another interactive totem application is the filter application (see Figure 5). In the filter application, the fan may watch the match with the colors of their team and the team insignia on the screen.

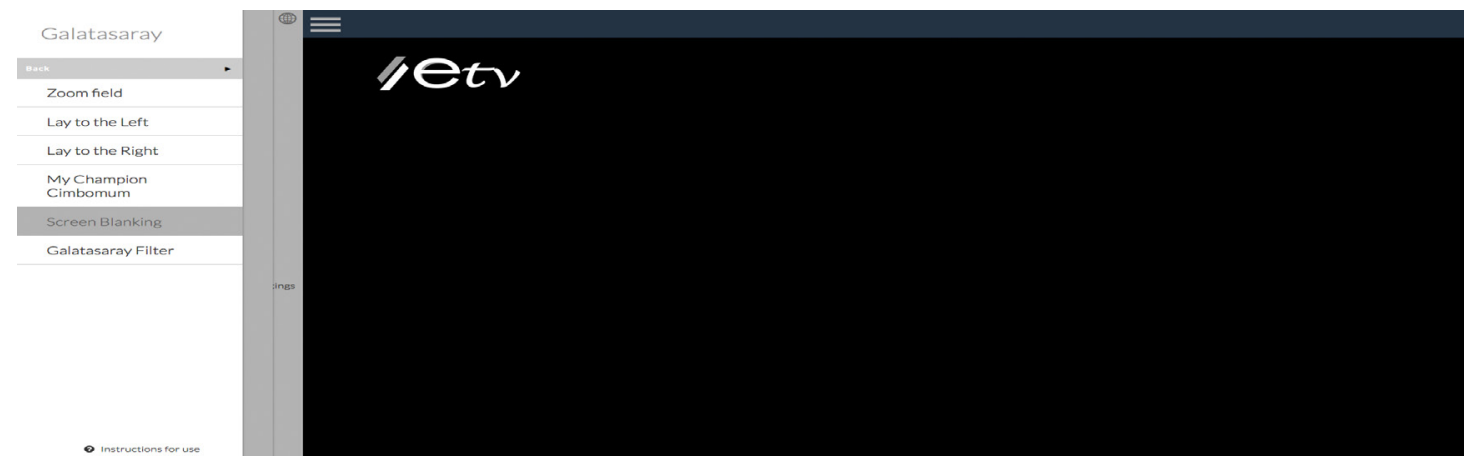

Figure 4: An Example of Interactive Screen Blackout.

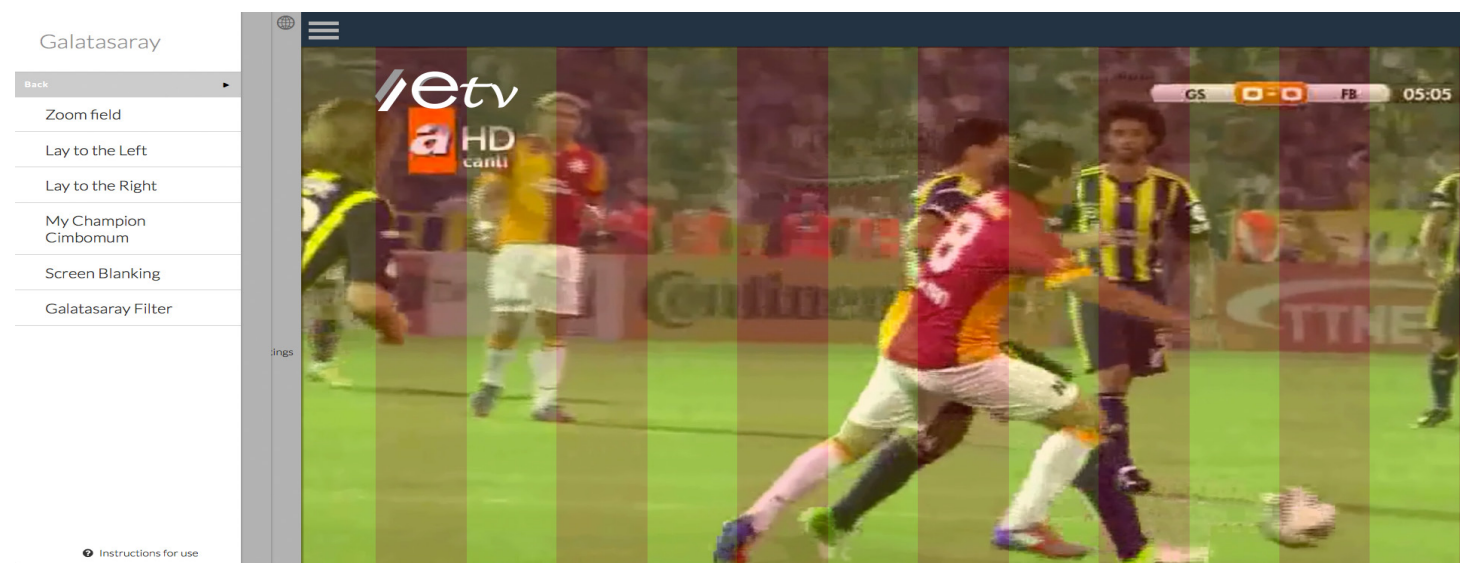

Figure 5: An Example of The Interactive Filter Application.

\section{Inclusion of support control elements in accordance with individual differences between participants}

Regarding the inclusion of support control elements, experts focused on the ease of use of the design by participants, contributing to the continuity of the content, and the importance of the target audience of the content. Direct quotes from experts given below; 
The important thing is issue of matching content with target audience. Generated content must be interesting, relevant and understandable by people. Design serving this function grantie will undergo usability testing with. (Bram)

Another expret, Kerim, says,

We have to configure the interface design as proportional to the level of education. For example, for elementary school person are given to help control elements such as more simple expression with guide and map navigation.

In this regard, when producing content for interactive television programs, the inclusion of a control system that may support all users in need of assistance - primarily children and the elderly - will ensure that the user utilizes the interface more willingly and more comfortably views the interactive content. For example, it is stated that children enjoy designs that encourage their use of cognitive skills, are easily understood, entertaining, and allow for personalization; youths prefer interfaces with a high concentration of moving images, and programs that include multiple choice options that require high levels of cognitive activity; middle aged and educated individuals prefer content with depth. Figure 6 portrays a support control element in the design regarding how the system is used for the user to more comfortably view in interactive football design.

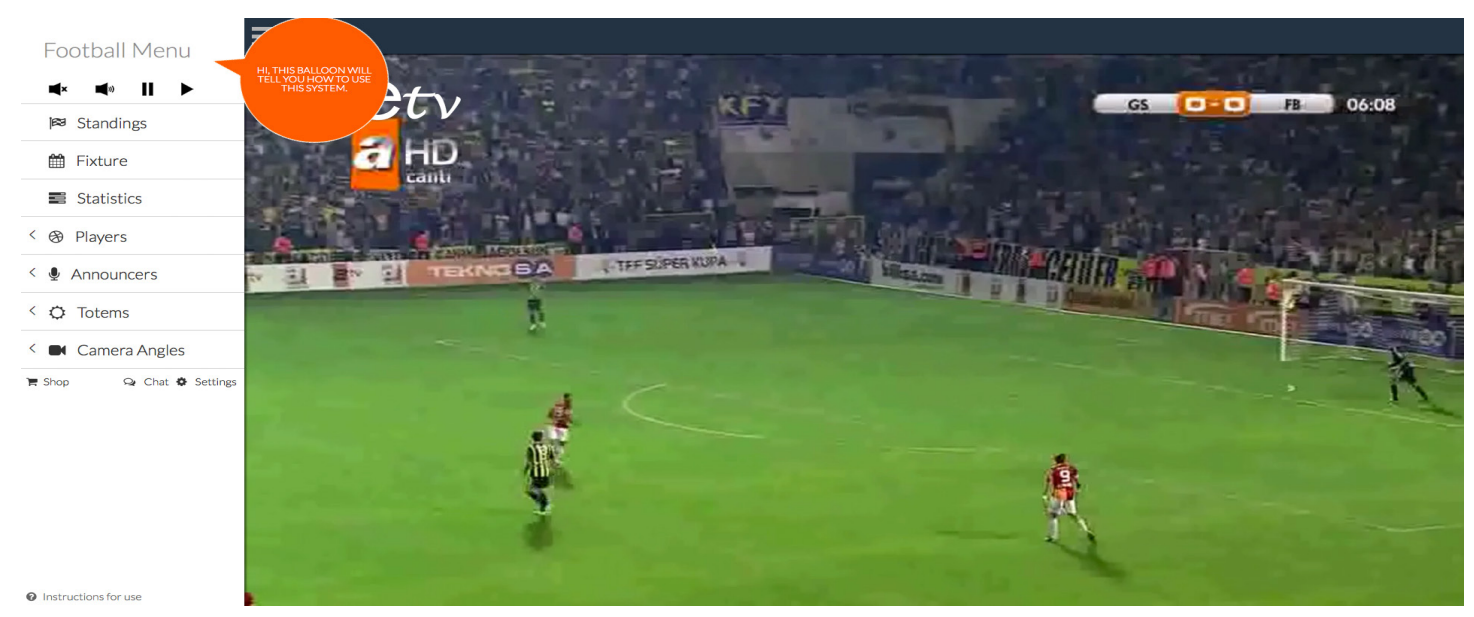

Figure 6: Support Control Element.

\section{Second screen application in interactive television broadcasting}

In addition to being a shared viewing activity between family members, the activity of watching television is also an activity that may offer an individual viewing experience through interactive applications such as the second screen. Direct quotes from experts given below;

The effect of the second screen as an interactive application is to provide access to information regarding the content while watching television, and to allow information sharing with other users thereby enriching the viewing experience through interactive environments. To ensure this, interactive content applications may be designed such that many people may communicate, interact and share simultaneously. (Anthony)

Another expret, Deniz, says; during the monitoring program television audience might want to share a content that require with one another. Thus data regarding television content carried out simultaneously among users. Besides it allows viewers to realize the current flow of information related to the content. 


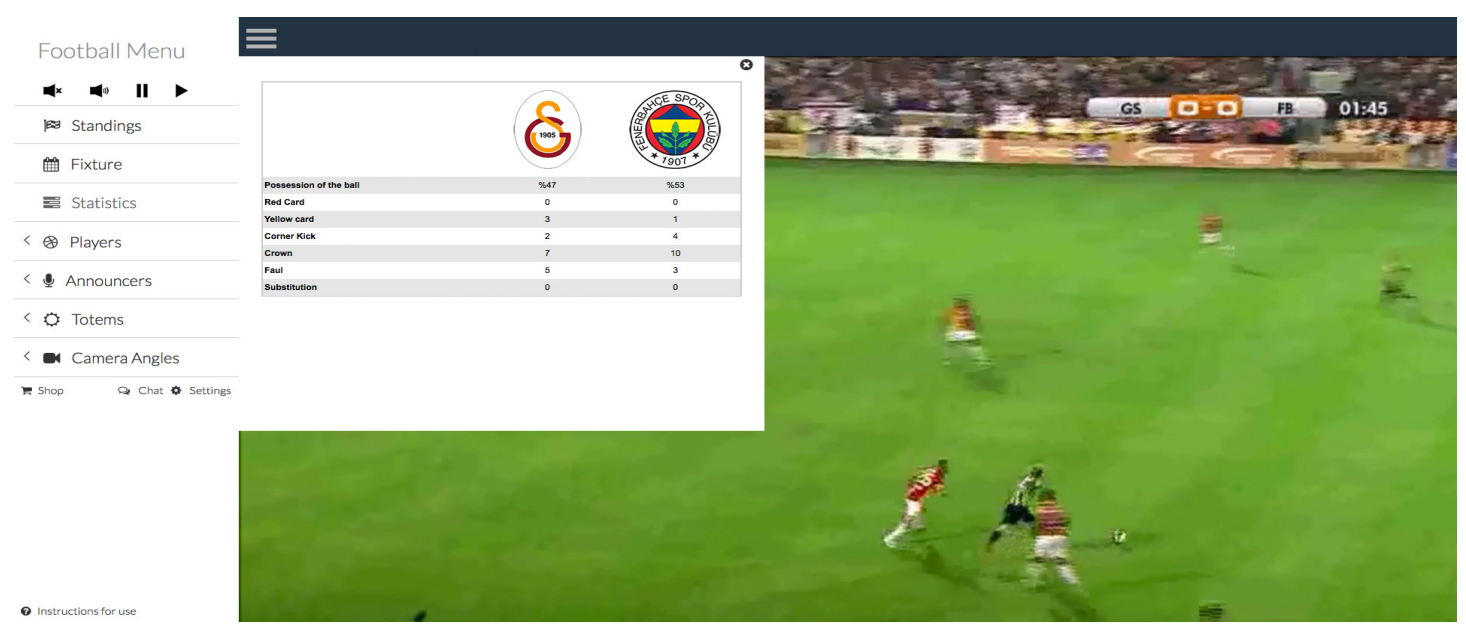

Figure 7: Second Screen Application.

In the interactive football application designed in accordance with the quotes, half of the screen contains the video feed while the other half provides information opportunities regarding the matches of the week (see Figure 7).

\section{Discussion and Conclusions}

This descriptive case study gathered expert opinions regarding the development process of design for interactive television broadcasting. The views of experts regarding interactive content design provided important clues for the determination and development of principles for interactive television content. Of the elements within the model, the process of establishing interactive content in accordance with the visual language and aesthetic of television refers to situations that may cause distraction in the television watching process; including online applications refers to applications that assist the viewer in accessing further information on the content; support control elements refer to participants easily using the design; and the second screen application refers to many people simultaneously sharing through their menus.

\section{Limitations and Recommendations for Future Research}

This study is limited to the design of an interactive football program based on data gathered from individual interviews and only covers engineering aspects such as data gathering, data compression, data transfer and interface selection with regards to interactive television broadcasting. The study is conducted as a case study and the participants of the study are academics and media professionals with at least five years of experience in the field, whom have an active role in the process of content design or whom have contributed to the literature in the field with national and international studies. The data gathered through individual interviews with 8 experts selected through purposive sampling was coded using the Nvivo10 software.

The following recommendations are made for future research in the process of interactive television broadcasting:

- The model developed regarding content design for interactive television broadcasting may be applied to other television program types.

- The model developed within this study may be evaluated by different viewership groups. Regarding the feedback of the research, the system may be further developed and updated. 
- Future studies may use and be conducted using a sample of different participant groups. Thus, new views on the general design principles determined for interactive television broadcasting may be presented, providing diversity regarding the design principles.

\section{References}

Abramson, A. (2003). The history of television, 1942 to 2000. USA: McFarland.

Akca, D. (2008). IPTV. Bilim ve Teknik, (485), 50-52.

Andrejevic, M. (2009). Critical media studies 2.0: An interactive upgrade. Interactions: Studies in Communication and Culture, 1(1), 35-51.

Athanasiadis, E. \& Mitropoulos, S. (2010). A distributed platform for personalized advertising in digital interactive tv environments. The Journal of Systems and Software, 83 (8), 1453-1469.

Baştan, S. (2009). Kuramdan uygulamaya etkileşimli iletişim tasarımı. Ankara: Nobel Yayınları.

Bayrak, M. (2008). IPTV ve içerik. İ. Yerlikaya, C. Dolanbay ve V. Ünal (Yay. haz.). Birey eksenli interaktif yayıncılık: IPTV içinde (s. 169-176). Ankara: RTÜK ve Türkiye Bilişim Derneği Yayını.

Berendt, A. (2008). IPTV: Old ambitions, new realities. Intermedia, 36(1), 4.

Bietz,M.(2008).Interactivtyandelectroniccommunication:AnExperimentalstudyofmediated feedback in Michigan Üniversitesi (Doctoral dissertation). Erişim tarihi: https:// pdfs.semanticscholar.org/a3a2/978bf26da3715db3d9c5ba36ed7dc10a2360.pdf.

Bouwman, H., Zhengjia, M., Van der Duin, P., \& Limonard, S. (2008). A business model for iptv service: a dynamic framework. Info, 10(3), 22-38.

Bruns, A. (2008). Blogs, Wikipedia, Second Life, and beyond: From production to produsage. New York: Peter Lang.

Cesar, P. ve Chorianopoulos, K. (2008). The evolution of tv systems, content, and users toward interactivity. Foundation and Trends in Human-Computer Interaction, 2(4), 279-373.

Chen, G. M. (2007). Media (Literacy) Education in The United States. China Media Research, $3(3), 87-103$.

Chung, S. D. ve Yoo, Y. C. (2008). Audience motivations for using interactive features: distinguishing use of different types of interactivity on an online newspaper. Mass Communication and Society, 11 (4), 375-397.

DiCicco, B. B. ve Crabtree, B. F. (2006). The qualitative research interview. Medical Education, 40 (4), 314-321.

Ersavaş, B. F. (2008). IPTV'de içerik paylaşımı. Yerlikaya, C. Dolanbay ve V. Ünal (Ed.), Birey Eksenli Interaktif Yayıncılık: IPTV, (pp. 271-286), Ankara: RTÜK ve Türkiye Bilişim Derneği Yayını.

Faber, G. (2011). Shifting power: How Google TV entered the living room. Unpublished doctoral thesis. Amsterdam: University of Amsterdam. 
Finnemann, O. N. (2011). Mediatization theory and digital media. Communications, 36 (1), 67-89.

Flick, U. (2014). An introduction to qualitative research. Los Angles: Sage Publications.

Garratt, G. R., and Mumford, A. H. (1952). The history of television. Proceedings of the IEEPart IIIA: Television, 99(17), 25-40.

Glesne, C. (2013). Nitel araştırmaya giriş. (2. baskı). (A. Ersoy ve P. Yalçınoğlu, Çev. Edt.). Ankara: Anı Yayıncılık.

Guimarães, R. L. (2009). The next generation of multimedia authoring tools: Telling stories and commenting on media. Networked Television Adjunct Eurol TV 2009, 171.

Ha, L. ve James, L. (1998). Interactivity reexamined: A baseline analysis of early business websites. Journal of Broadcasting \& Electronic Media, 42(4), 457-474.

Hobbs, R. (2010). Digital and media literacy: a plan of action. Washington, D.C.: The Aspen Institute.

Jensen, J. F. (1998). 'Interactivity' tracking a new concept and communication studies. Nordicom Review, 19(1), 185-204.

Kim, P. (2009). Internet protocol TV in perspective a matrix of continuity and innovation. Television \& New Media, 10(6), 536-545.

Kim, P. \& Sawhney, H. (2002). A machine-like new medium-theoretical examination of interactive TV. Media, Culture \& Society. 24(2), 217-233.

Kiousis, S. (2002). Interactivity: a concept explication. New Media \& Society, 4 (3), 355383.

Liu, Y. ve Shrum. (2002). What is interactivity and is it always such a good thing? Implications of definition, person, and situation for the influence of interactivity on advertising effectiveness. Journal of Advertising, 31(4), 53-64.

Lotz, A. D. (2014). The television will be revolutionized. New York: NYU Press.

Napoli, P. M. (2011). Audience evolution: New technologies and the transformation of media audiences. New York: Columbia University Press.

OxfordDictionary(2013).Interactive.Erișimadresi(23.01.2013):http://oxforddictionaries. com/definition/american_english/interactive?q=interactivity\#interactive_9.

Pagani, M. (2000). Multimedia and interactive digital TV: Managing the opportunities created by digital convergence: managing the opportunities created by digital convergence. IGI Global.

Patton, M. Q. (2002). Qualitative research \& evaluation methods (3rd edition), Hershey PA: Sage Publications.

Rafaeli, S. (1988). Interactivity: From new media to communication. R. P. Hawkins, J. M. Wiemann \& S. Pingree (Eds.), In advancing communication sicience: merging mass and interpersonel process (pp. 34-100), Thousands Oaks, CA: Sage.

Richards, R. (2006). Users, interactivity and generation. New Media \& Society, 8(4), 531550.

Rogers, Y., Sharp, H. ve Preece, J. (2011). Interaction design: Beyond human-computer interaction (3rd edition). United Kingdom: John Wiley \& Sons. 
Quiring, 0. (2009). What do users associated with 'interactivity'?: A qualitative study on user schema. New Media \& Society, 11(6), 899-920.

Tsekleves, E., Cosmas, J., Aggoun, A., \& Loo, J. (2009). Converged digital TV services: The role of middleware and future directions of interactive television. International Journal of Digital Multimedia Broadcasting, 2009, 1-19.

Ünaldı, A. (2010). Türkiye'de IPTV. Kasım 2009 IPTV Derneği Raporu. Erișim adresi (25.02.2013):http://atifunaldi.com.tr/2010/07/29/turkiye\%E2\%80\%99de-iptvkasim-2009-iptv-dernegi-raporu/

Van Dijck, J. (2013). The culture of connectivity: A critical history of social media. New York: Oxford University Press.

Van Dijk, J.A ve De Vos, L. (2001). Searching for the holy grail images of interactive television. New Media \& Society, 3 (4), 443-465.

Yüzer, V. (2013). Uzaktan öğrenmede etkileşimlilik, Ankara: Kültür Ajans Yayınları. 


\title{
Etkileşimli Televizyon Yayıncılığında İçerik Geliştirme
}

\author{
Birgül Taşdelen (Dr. Öğr. Üyesi) \\ Mehmet Kesim (Prof. Dr.)
}

\section{Genişletilmiş Özet}

Etkileşimli televizyon yayın teknolojisi, teknik alt yapısı ve kullanıcısına sunduğu hizmetler itibariyle televizyon yayıncılığının genişletilmiş biçimidir (Berendt, 2008, s. 6). Televizyonun ortaya çıktığından beri yaşanan gelişmeleri dönemlere ayırarak açıklanmaya çalışılırsa ilk dönem, 1931 yılında sorunsuz olarak çalışan siyah-beyaz televizyonun ortaya çıkışı (Garratt and Mumford, 1952, s. 34), ikinci dönem siyah-beyaz yayınların yerini 1950'li yıllarda renkli yayınlara bırakması (Abramson, 2003, s. x), üçüncü dönem yirminci yüzyılın ikinci yarısı ile beraber sayısal yayıncılığın başlaması ve son olarak 2000'li yılların başında telekomünikasyon, sayısal televizyon yayıncılığı ve internetin birleşmeye başlaması ile etkileşimli televizyon yayıncılığına geçiş (Tsekleves, Cosmas, Aggoun and Loo, 2009, s. 2) olarak sinıflandırılabilir. Finnemann'a (2011, s. 8485) göre, makro düzeyde bütün toplumlar, sayısal medyanın etkileşimli olma potansiyeli ile dördüncü matristen, beşinci matrise doğru bir hal değişikliği içerisindedir. Bu aşama, geleneksel medyanın kendisini internete, mobil hizmetlere ve etkileşimli lokasyona duyarlı iletişim ortamlarına dönüștürdüğü bir yapıdır. Bruns'a $(2008$, s. 23) göre bu matriste geleneksel medya araçları içerisinden seçim yapan ve dinleyici, okuyucu ve izleyici olarak yer alan kişiler aynı zamanda yeni iletişim teknolojileri aracılığıyla üretici, kullanıcı ve gönderici olarak da konumlanmaktadır. Böylece günlük yaşamda uyguladıkları pratikleri kendilerine ait katılımcı profilleriyle birlikte çevrimiçi platformlara taşımaktadırlar (Van Dijck, 2013, s. 6). Yeni teknolojik donanımlara sahip iletişim uygulamaları, geleneksel kitle iletişim araçlarının klasik yapısını da değiștirmektedir. İçinde yaşadığımız yirmibirinci yüzyılın ilk çeyreğinde kişilerin, televizyon yayıncılığında genişbantlı internet erişim ağı ve mobil telefonlar aracılığıyla gerçekleştirilen etkileşimli eylemlerle sürekli iletişim halinde olduklarını söylemek mümükündür. Yeni iletişim teknolojilerinin gelişimi ve hızlı enformasyon akışı sayesinde kişilerin sayısal medya kültürüne katılarak, yeni biçimler oluşturması ve yeni deneyimler yaşaması sağlanmaktadır (Hobbs, 2010, s. 15).

Yeni medya çalışmalarının ve sayısal kültürün temel kavramlarından biri etkileşimliliktir. Araştırmaların birincil amacı etkileşim olduğunda geleneksel medya çalışmaları için büyük bir zorluk ve mahrumiyet ortaya çıkmaktadır. Yirminci yüzyıl kitle iletişim araçları ile ilgili gelenekselyaklaşımların güncel iletişim araçlarının oluşturduklarıyeni oluşum ve kavramları yorumlamada zayıf kalmasının temel nedeni, geleneksel yaklaşımların tarih boyunca tek yönlü ileti modeline göre yapılandırılmış olmalarıdır (Napoli, 2008, s. 11). Dolayısıyla farklı bir medya matrisinin (dizeyinin) inşa edilmesine ön ayak olan internet, sayısal televizyon ve mobil cihazlar etrafında oluşan yeni yönelimler ve yapısal değişiklikler kitle iletişimindeki birçok model ve kavramların yeniden gözden geçirilme ihtiyacını ortaya çıkarmaktadır (Jensen, 1998, s. 187; Kiousis, 2002, s. 355). Medyanın önemini değiştiren bu eleştirel anlayış, reklamların tüketici davranışları üzerindeki etkileri ya da insanların medyayı hangi amaçla kullandıkları gibi geleneksel sorulara yanıt aramamaktadır. Son on yılda iletişim bilimlerindeki yeni yönelim, etkileşimliliğin neden olduğu olguları anlamlandırmaktır. İnternet çağının başlangıcından beri etkileşimliliğin neden olduğu olguları tanımlamaya ve anlamlandırmaya yönelik çalışmalar iletişim bilimlerin temel konuları arasında yer almaktadır (Van Dijk and De Vos, 2001, s. 447-448; Chung ve Yoo, 2008, s. 376). Bu tarz 
iletişime uygun yeni iletişim deneyimlerine aracılık eden uygulama biçimleri, merkezi bir enformasyon üreticisi tarafından kontrol edilebilen ve tek tip içeriğin kitlelere dağıtıldığı geleneksel kitle iletişim araçlarından sunulan içeriği ters yüz eden, kendisiyle tümleştiren iş modellerinin üretilmesine olanak vermektedir. Etkileşimli TV'nin gerçek anlamda diğer yayıncılık yöntemlerine alternatif olabilmesi için gerekli olan en önemli araçlardan birisi içeriktir. Bu nedenle, başarılı bir etkileşimli servis için sadece altyapı kurmanın ve izleyiciye güzel arayüzler sunmanın yeterli olmadığı, başarıya ulaşmada en büyük kozun içerik üretmek olduğu düşünülmektedir (Bayrak, 2008, s. 175). Bu durum etkileşimli televizyon konusunda ciddi anlamda içerik üreticilerinin etkin olabileceği bir yapının ortaya çıkacağını göstermektedir. Bundan dolayı etkileşimli televizyon yayıncılığı için içerik geliştirmenin, diğer bir ifade ile kullanıcılara rağbet gösterecekleri içeriklerin sunulmasının sistemin gelişmesine sağlayacağı katkıları araştırmak önemlidir. Bu çalışmanın konusu, etkileşimli televizyon yayıncılığına yönelik etkileşimli bir modelin tasarlanması ile ilgilidir. Bu çalışmada ilk olarak, Hollanda, ABD, Avustralya, Singapur ve Türkiye'den çalışmaya katılmayı kabul eden etkileşimli televizyon ve etkileşimli içerik konusunda deneyimli sekiz uzmanın görüşleri alınmıştır. Bu nedenle araştırma, nitel bir durum çalışması şeklinde desenlenmiştir. Elde edilen veriler doğrultusunda, etkileşimli televizyon uygulamalarının 4 ana tema ile gerçekleştirileceği sonucuna ulaşılmıştır. Bu temalar; televizyonun görsel diline ve estetiğine uygun etkileşimli içerik oluşturma, etkileşimli televizyon yayıncılığında ikinci ekran uygulaması, katılımcıların bireysel farklılıklarına uygun olarak destek kontrol unsurların yer alması ve çevrimiçi uygulamalara yer vermedir. Sürecin ikinci aşamasında ise, bireysel görüşmelerden elde edilen veriler doğrultusunda etkileşimli bir futbol programının tasarımı gerçekleștirilmiştir. Bu araştırmanın bulgularına göre çalıșmanın sonuçları şu şekildedir:

(1) Kurum ve kuruluşlar (özel ve devlete ait radyo ve televizyon kuruluşları, medya şirketleri vb.) televizyon dilini ve beğeni kurallarını göz önünde bulundurarak televizyon yönetim paradigmasını takip etmek durumundadır.

(2)Etkileşimli içerikleri birçok insanın aynı anda iletişim, etkileşim ve paylaşımın gerçekleştirebileceği şekilde tasarlanmalıdır.

(3) Televizyon izleme etkinliğini geliştirmek için içerikleri tamamlayıcı, güncel eğilimlerle güçlendirilmiş Web tabanlı sayfalar tasarlanmalıdır.

(4) Uygulamaları tasarlarken, hedef kitlenin özellikleri dikkate alınmalıdır.

(5) İçerik sağlayacılar, kullanıcıların zorlanmayacakları etkileşimli uygulamalar sunmalıdır.

(6)Ekrandaki genel bilgilerin varlığını desteklemek yerine eğlence etkinliklerin arttırılması için çaba sarfedimelidir. Tasarımcılar televizyounun ana içeriğiyle uyuşan eğlencenin ve bilginin aynı anda sunulduğu etkileşimli eğlence unsurları geliştirmelidir.

(7) İçerik sağlayacılar tüketicilerin içeriklere istedikleri yer ve zamanda ulaşabilmesini sağlayacak ve iste-izle (VoD), çok kanallı televizyon yayınları ve kablosuz oyunlar vb. multimedya içerik uygulamalarını içeren hizmetleri birarada sunabilecek etkileşim uygulamaları tasarlamaları için çaba göstermelidir.

(8) Kullanıcının arayüzü rahatlıkla kullanabilmesini sağlayacak Etkileşimli Program Klavuzu'na yer verilmelidir.

Anahtar Kelimeler: Etkileşim, Etkileşimli Televizyon, Nitel Araştırma, Etkileşimli Futbol Tasarımı. 